DOI https://doi.org/10.30525/978-9934-26-039-1-83

\title{
SURVIVAL STORYTELLING IN ANTI-TRAFFICKING SOCIAL CAMPAIGNS
}

\author{
Paliichuk E. O. \\ Ph. D. in Philology, \\ Assistant Professor at the Chair of English Philology and Translation \\ Institute of Philology of the Borys Grinchenko Kyiv University \\ Kyiv, Ukraine
}

Nowadays people are increasingly living in mediated realities consuming the information through pre-constructed models that structure our perception of the hottest events: pandemic, elections, political shifts, trade in human beings, multiculturalism, tolerance, environment, migration, technologies, security, etc. The issues of shaping social beliefs have become the subject matter not only of linguistics but also of the transdisciplinary research, in particular, in the framework of medialinguistics, discourse analysis, cognitive science.

The mediated realities are modelled with the help of the strategies based on activation of cognitive structures such as frames, metaphors, scenarios, symbols, iconic structures. One of such strategies is storytelling. Based on specific cognitive models such as scenarios, stories serve as means of getting ideas across the audience.

Human trafficking has been the global concern for over decades despite the efforts made by governments, law enforcement bodies and international organizations. The problem persists and requires effective methods of raising awareness among population through media instruments. The use of the research methods available within the domain of philology can provide for the data about the textual techniques used in media products aimed at combatting human trafficking [1].

Specifically, the focus on the mechanism of the influence of media messages on collective consciousness contributes to the development of effective strategies used in anti-trafficking social campaigns aimed at raising awareness among vulnerable categories of population: the unemployed, women and girls, seasonal workers and migrant laborers.

In the framework of trade in human beings, survival storytelling has become one of the most widespread methods of warning potential victims about danger of getting into the trafficking network as a result of their possible actions related to migration, employment abroad, marriage with foreigners, 
studying, tourism, etc. Therefore, the narrative as a certain type of construal is brought into focus in this study. In particular, the research is aimed at establishment of the typical narrative model of the stories used in the social campaign of Equality Now [2] international organization.

The strategy of using personal narratives in social campaigns provides for as-if-unbiased representation of the situation. Avoiding direct viewpoints, media would resort to subtle mechanisms of shaping public opinion. The typified stories are used as scenarios for showing the peripetia of illegal transporting of migrants, travelers, men, women and children sold into slavery.

The survival storytelling strategy involves narrative framing, with stories told by the human trafficking victims. Focalizing [3] on a victim's account from 1st person, the so-called "story of the self» [4, p. 36)], provides an impressive textual close-up shot. The observations show that a key feature of the stories is that they are retrospective. The flashbacks comprise: 1) description of settings and social background, circumstances and causes of getting into the trafficking net; 2) the offer made by a trafficker and a reaction thereto; 3 ) getting into a trafficking scheme: illegal transportation, loss of documents, loss of rights, illegal migration, forgery, deception, coercion, labour exploitation, sex exploitation, etc.; the actions made with a victim are zoomed, her feelings are brought to light (rendering of aural and tactile senses is enhanced); 4) possible escape; 5) the future is rather vague.

The cutback refers to the representation of the initial circumstances under which young girls fall victims. The setting is shown as poor economic conditions, domestic or social violence, be it in a rural or urban location, these are elements of the beginning of a story: Lowyal was 13 years old when kids started bullying her everyday at school. ... Eventually, her "friends» introduced her to «the game» and started walking the stroll under the constant threat of pimps and johns [2].

The turning point is the action which starts as soon as a potential victim reacts to a lure. She would receive a prospective offer from a trafficker, or her relatives would be promised certain amount for her being sold. Victim's initial actions are shown scarcely. As soon as a victim contacts a trafficker, she finds herself in slavery conditions, - forced, coerced, and exploited. Focalisation on victim's passiveness enhances the effect of danger. At this stage, the helpless condition of a victim is zoomed: she becomes deprived of her documents, enslaved, and forced to work as a prostitute; losing identity, she becomes an object undergoing the actions made by traffickers, which is magnified in a story due to tactile and sound images: I've been tortured and abused ... cried, screamed... [2]. 
Such narrative has no climax, with a fact of breaking free just being stated. The accent is shifted to denouement: She ran away and was picked up .... Today, she's a brilliant poet and spoken word artist ... [2]. A victim's life is broken into past and present, with her future being vague: "In my eyes, everything was ruined and just burning." Today, Lowyal is back at school...» [2].

This sequence of events constitutes a typical scenario in the human trafficking representation in social campaign underlying the survival storytelling technique. The results are valuable for an empirical research aimed verifying reader's response to the human trafficking survivor stories.

\title{
References:
}

1. Paliichuk E. Storytelling in English-Language Anti-Trafficking Campaign: A Cognitive Perspective. Studia Philologica. 2018. No.2 (11). P. 100-106. DOI: https://doi.org/10.28925/2311-2425.2018.11.16

2. Equality Now. A Just World for Women and Girls. URL: https://www.equalitynow.org/stories_of_survivors (Retrieved on 16 February 2021)

3. Langacker, R.W. Foundations of Cognitive Grammar. Theoretical Prerequisites. Stanford: Stanford University Press, 1987. V. 1. 516 p.

4. Mills, P. The Routledge Creative Writing Coursebook. London and New York: Routledge. 2006. 256 p.

DOI https://doi.org/10.30525/978-9934-26-039-1-84

\section{ПСИХОЛІНГВІСТИЧНІ ОСОБЛИВОСТІ ТЕКСТІВ КНИЖКОВИХ АНОТАЦІЙ}

\author{
Полтавець Ю. С. \\ кандидат філологічних наук, \\ старший викладач кафедри журналістики \\ факультету української філології та літературної творчості \\ імені Андрія Малишка
}

Начіонального педагогічного університету імені М. П. Драгоманова м. Київ, Украӥна

Книжкові анотації є важливим засобом комунікації між видавництвом і читачами. Вони формують образ видання у свідомості потенційних читачів, і щоб він був позитивним та щоб в адресата виникла потреба 106 